\title{
COVID-19: Alarm Bagi Sistem Rantai Pasok Industri Farmasi
}

\author{
Monica Richelle Herdady ${ }^{*}$, , Muchtaridi Muchtaridi2 \\ ${ }^{1}$ Program Studi Profesi Apoteker, Fakultas Farmasi, Universitas Padjadjaran \\ 2Departemen Analisis Farmasi dan Kimia Medisinal, Fakultas Farmasi, Universitas Padjadjaran \\ *E-mail: monicaherdady@gmail.com \\ (Submit 26/6/2020, Revisi 2/5/2020, Diterima 21/5/2020)
}

\begin{abstract}
Abstrak
Wabah pandemi COVID-19 merupakan peristiwa yang berdampak besar secara global dalam waktu singkat. Hampir seluruh sektor terpengaruh akibat wabah ini, salah satunya adalah sektor industri farmasi. Keberlanjutan rantai pasok perbekalan farmasi menjadi persoalan akibat pembatasan aktivitas di berbagai wilayah. Apabila wabah ini terus berlanjut maka stok dari perbekalan farmasi serta bahan baku farmasi berpotensi kian menipis yang dapat menyebabkan kelangkaan dalam skala yang lebih besar. Oleh sebab itu, artikel ulasan ini dibuat untuk membahas dampak COVID-19 terhadap sistem rantai pasok industri farmasi dan strategi yang dapat dilakukan oleh industri farmasi di tengah masa pandemi COVID-19. Strategi-strategi yang dapat dilakukan oleh industri farmasi saat ini adalah melakukan manajemen dalam aspek persediaan, informasi serta finansial untuk menopang operasional industri agar dapat melewati masa pandemi ini.
\end{abstract}

Kata Kunci: COVID-19, Industri Farmasi, Rantai Pasok, Strategi, Manajemen Persediaan, Manajemen Informasi, Manajemen Finansial Kata kunci minimal ada lima

\section{Outline}

- Pendahuluan

- Metode

- Hasil dan Pembahasan

- Kesimpulan

- Daftar Pustaka

\section{Pendahuluan}

Wabah pandemi Coronavirus Disease 2019 yang dikenal dengan COVID-19 sudah berlangsung sejak akhir tahun 2019. COVID-19 merupakan penyakit menular yang menyerang sistem pernapasan dan disebabkan oleh coronavirus yang ditemukan pertama kali di Wuhan, China pada akhir bulan Desember 2019². Lembaga Kesehatan Dunia atau WHO menyatakan COVID-19 sebagai pandemik sejak pertengahan Maret 2020. Data WHO per tanggal 24 April 2020 menunjukkan sudah 209 negara terjangkit dengan jumlah kasus secara global sebanyak 2.626.321 kasus dan angka kematian mencapai 181.938 jiwa $^{2}$. Indonesia menjadi salah satu negara yang terjangkit COVID19 dengan total kasus mencapai 8.211 kasus. 
Berdasarkan data $\mathrm{BNPB}^{3}$, angka kejadian di Indonesia per tanggal 24 April 2020 sudah menembus angka lebih dari 8.000 kasus dengan total lebih dari 600 orang meninggal dan lebih dari 1.000 orang yang sembuh. Peningkatan kasus tertinggi juga pernah terjadi pada tanggal 9 April 2020 dengan jumlah pertambahan sebanyak 436 kasus.

Dampak yang ditimbulkan oleh wabah ini begitu masif sampai dapat melumpuhkan aktivitas perekonomian global di berbagai sektor bisnis. Kerugian ekonomi yang dialami China akibat virus 2019-nCov diestimasikan mencapai USD 62 juta dan total kerugian lebih dari USD 280 juta secara global pada kuartal pertama tahun $2020^{4,5}$. Indonesia diprediksi mengalami penurunan Pendapatan Domestik Bruto (PDB) sebesar $0.2 \%$ dari tahun $2019^{6}$. Salah satu kegiatan operasional sektor bisnis yang terkena dampak akibat wabah ini adalah kegiatan rantai pasok. Rantai pasok merupakan serangkaian sistem yang terdiri atas organisasi, personel, aktivitas, informasi, dan segala jenis sumber daya lainnya terkait kegiatan memasok produk bagi konsumen ${ }^{7}$.

Aktivitas dalam rantai pasok tidak dapat dihindari dari risiko terjadinya gangguan. Gangguan yang terjadi pada rantai pasok berupa fluktuasi permintaan serta perubahan lama waktu pemesanan (lead time) merupakan gangguan operasional yang lazim terjadi pada rantai pasok. Namun gangguan berbentuk wabah pandemi seperti yang terjadi saat ini merupakan gangguan rantai pasok yang terjadi secara tiba-tiba dan dapat disebut sebagai disrupsi rantai pasok ${ }^{8}$. Contoh dari disrupsi rantai pasok adalah peristiwa bencana alam seperti gempa dan tsunami, bencana akibat manusia seperti peristiwa ledakan di pabrik kimia, dan sengekta hukum ${ }^{9}$. Disrupsi rantai pasok ini menyebabkan dampak terhadap struktur rantai pasok perusahaan seperti terputusnya jaringan transportasi yang menyebabkan terjadinya penundaan distribusi barang hingga kelangkaan barang. Rantai pasok yang terputus menyebabkan penurunan performa perusahaan sehingga mengakibatkan penurunan pendapatan ${ }^{10}$.

\section{Pengaruh COVID-19 Terhadap Industri Farmasi}

Berbagai macam sektor bisnis terdampak dari pandemi COVID-19 ini, salah satunya adalah sektor industri farmasi di berbagai belahan dunia. Ozili dan Arun menyatakan bahwa sebanyak $60 \%$ bahan baku aktif farmasi yang digunakan seluruh dunia merupakan hasil produksi China ${ }^{11}$. Rude menyebutkan bahwa industri farmasi di berbagai belahan dunia sangat bergantung terhadap pasokan bahan baku obat dari China sejak tahun 2013. Pada tahun 2018, China merupakan produsen bidang farmasi terbesar di dunia yang mencakup $32,2 \%$ produk farmasi yang mengalami peningkatan dari persentase $26,5 \%$ sejak tahun 2013. Hal ini menyebabkan Cina menduduki posisi nomor satu sebagai produsen bahan baku farmasi ${ }^{12}$.

Hingga saat ini, industri farmasi di Indonesia masih mengandalkan impor sekitar $90 \%$ bahan baku obat-obatan yang digunakan dalam proses manufaktur obat dari luar negeri. Nilai impor ini mencapai USD 2,5 miliar hingga USD 2,7 miliar per tahunnya ${ }^{13}$. China dan India merupakan dua negara eksportir bahan baku farmasi terbesar ke banyak negara, termasuk Indonesia. Perusahaan-perusahaan yang berlokasi di China umumnya membuat kebijakan menurunkan kecepatan produksi atau bahkan meliburkan para pekerja sejak akhir bulan Januari karena hari raya Tahun Baru Imlek dengan kisaran waktu 1 hingga 2 minggu setiap tahunnya. 
Oleh sebab itu, biasanya para pelaku usaha yang berdagang dengan perusahaan asal China sudah menyiapkan stok persediaan sebagai langkah antisipasi akibat waktu libur tersebut. Namun kasus-kasus yang bermunculan di berbagai wilayah di China menyebabkan banyak perusahaan China yang memutuskan untuk menutup pabriknya sampai batas waktu yang tidak ditentukan dengan alasan untuk mencegah para pekerja melakukan kontak satu sama lain sehingga mengurangi kemungkinan lonjakan angka kasus COVID-1914. Selain itu, provinsi Hubei sebagai tempat asal COVID-19 dan salah satu sentrum industri farmasi di China memberlakukan sistem lockdown dan pembatasan aktivitas. Salah satu bentuk pembatasan aktivitas yang diperintahkan oleh lembaga berwenang setempat adalah penutupan industri sebagai langkah pengendalian persebaran virus. Walaupun kini China sudah mulai mengangkat peraturan lockdown, aktivitas manufaktur yang sebelumnya berhenti total tetap membutuhkan waktu dan proses secara bertahap untuk dapat kembali dilakukan dalam skala penuh. Penutupan industri, lockdown serta pembatasan aktivitas di negara China menyebabkan produktivitas dari negara tersebut menurun sehingga menyebabkan kegiatan ekspor tersendat, termasuk ekspor bahan baku obat. Muhammad Khayam selaku Direktur Jenderal Industri Kimia, Tekstil, dan Farmasi (IKTF) Kementerian Perindustrian Republik Indonesia juga mengimbau industri farmasi di Indonesia untuk segera mencari alternatif sumber bahan baku obat dari negara Cina ${ }^{15}$.

Selain itu, India sebagai alternatif sumber pemasok bahan baku farmasi juga turut memberlakukan lockdown tingkat nasional. Kebijakan tersebut juga diikuti dengan pembatasan ekspor 26 jenis bahan baku dan formulasi yang mengandung bahan baku farmasi oleh Kementerian Perdagangan dan Industri India (Ministry of Commerce \& Industry). Beberapa bahan baku farmasi yang termasuk dalam pembatasan ekspor diantaranya adalah bahan baku analgesik parasetamol, antibiotik klindamisin, serta antivirus acyclovir. Pembatasan tersebut dilakukan sebagai upaya pemerintah India untuk memastikan kebutuhan pasokan obat secara nasional dapat terpenuhi dan berlaku efektif hingga batas waktu yang belum ditentukan. Hal ini berpotensi menimbulkan masalah terhambatnya alur rantai pasok farmasi secara global termasuk Indonesia. Berikut adalah daftar bahan baku farmasi yang dibatasi ekspornya oleh Kementerian Perdagangan dan Industri India:

Tabel 1 Daftar Bahan Baku Farmasi yang Terdampak Pembatasan Ekspor oleh Pemerintah India ${ }^{16}$

\begin{tabular}{|lllll|}
\hline Analgesik & \multicolumn{1}{c}{ Antibiotik } & Antivirus & Vitamin & Lain-lain \\
\hline Parasetamol & Chloramphenicol & Acyclovir & Vitamin B1 & Progesterone \\
\hline & Neomycin & & Vitamin B6 & \\
& Garam & & \\
& Erythromycin & Vitamin B12 & \\
\hline & Garam Clindamycin & \\
\hline & Tinidazole & \\
\hline & Metronidazole & \\
\hline & Ornidazole & \\
\hline
\end{tabular}


Dampak jangka pendek belum tentu dirasakan oleh industri farmasi nasional. Setiap industri pasti memiliki persediaan yang dapat bertahan hingga beberapa waktu kedepan. Ketua Komite Perdagangan dan Industri Bahan Baku Farmasi Gabungan Pengusaha (GP) Farmasi, Vincent Harijanto, menyatakan bahwa stok bahan baku farmasi masih dapat mencukupi kebutuhan produksi hingga April ${ }^{17}$. Namun dalam jangka panjang wabah virus ini berpotensi menyebabkan masalah terhadap keberlangsungan rantai pasok dan terhambatnya proses manufaktur industri farmasi akibat pembatasan aktivitas.

\section{Nasib Industri Farmasi di tengah Wabah COVID-19}

Wabah COVID-19 menguji kesiapan dan kematangan sistem rantai pasok industri farmasi. Penelitian dari lembaga konsultan analisis data, GlobalData, melaporkan bahwa sebanyak $95 \%$ responden yang merupakan tenaga profesional di bidang industri kesehatan merasa khawatir terhadap dampak COVID-19 terhadap performa perusahaan, dengan responden dari wilayan Asia Pasifik yang menyatakan tingkat kekahwatiran tertinggi ${ }^{18}$. Kekhawatiran ini menandakan industri farmasi tidak sepenuhnya siap menghadapi wabah COVID-19, seperti perusahaan yang tidak mempunyai sumber bahan baku alternatif dan tidak melakukan perencanaan matang terkait pemasok, status persediaan barang, serta tidak memiliki alur logistik yang fleksibel.

Berbeda hal dengan sejumlah industri yang lebih siap dalam menghadapi dampak wabah COVID-19 dibanding industri lain. Industri yang siap adalah industri yang sudah memiliki perencanaan rantai pasok yang matang dan memiliki strategi persediaan yang baik, seperti memiliki pemasok dari berbagai wilayah sebagai upaya mitigasi terhadap risiko terhambatnya rantai pasok karena pembatasan di satu wilayah. Perusahaan farmasi internasional seperti AstraZeneca, Pfizer, dan GSK serempak merilis pernyataan kesiapan perusahaan menghadapi wabah COVID-19 termasuk dari segi rantai pasok ${ }^{19,20,21}$. Dalam pernyataan ketiga perusahaan disebutkan bahwa masingmasing perusahaan memantau setiap aspek rantai pasok secara proaktif dan berkelanjutan dalam situasi yang setiap hari berubah.

\section{Strategi Industri Farmasi Menghadapi Dampak COVID-19}

Industri farmasi kini harus memutar otak untuk menjaga kelancaran arus rantai pasok sehingga dapat dikatakan sebagai industri yang memiliki rantai pasok yang tangguh. Sifat ketangguhan rantai pasok dapat didefinisikan sebagai kemampuan adaptasi industri untuk mempersiapkan, merespons, dan kembali bangkit dari segala macam gangguan rantai pasok ${ }^{22}$. Hal ini dapat dicapai dengan mengedepankan prinsip-prinsip ketangguhan rantai pasok, yaitu fleksibel, kolaboratif, dan cepat tanggap ${ }^{23}$. Berdasarkan prinsip-prinsip tersebut, strategi yang dapat dilakukan oleh industri farmasi dalam rangka menghadapi wabah COVID-19 dapat dikategorikan ke dalam tiga aspek manajemen rantai pasok, yaitu pengelolaan persediaan, manajemen informasi, serta pengelolaan finansial perusahaan ${ }^{24}$. 
Dalam industri farmasi, manajemen persediaan merupakan kunci utama dalam pengelolaan rantai pasok. Dalam masa pandemi ini, industri farmasi harus mengupayakan agar stok pengaman tetap terjaga dengan mengembangkan strategi persediaan yang adaptif terhadap situasi dengan cara melakukan simulasi skenarioskenario inventory tertentu dan dampaknya terhadap tingkat persediaan dan biaya. Salah satu metode yang dapat digunakan untuk menguji strategi persediaan adalah dengan metode simulasi. Simulasi merupakan analisis pemodelan yang berguna dalam analisis gangguan rantai pasok ketika gangguan yang berdampak terhadap rantai pasok perli dianalisis dalam kondisi perubahan yang tergantung waktu ${ }^{25,26}$. Salah satu metode simulasi yang paling umum digunakan adalah metode Simulasi Monte Carlo, yakni analisis risiko dengan menggunakan persamaan matematika terkomputerisasi yang memungkinkan perhitungan risiko secara kuantitatif berdasarkan variabel acak.

Dalam hal ini, gangguan yang terjadi pada rantai pasok dapat disimulasikan dan diukur dengan model Monte Carlo ${ }^{27}$. Umumnya pemodelan simulasi menggunakan perangkat lunak seperti anyLogistix, @Risk, dan Crystal Ball Ketiganya digunakan dalam sistem rantai pasok dimana @Risk dan Crystal Ball merupakan perangkat lunak yang lebih sederhana karena merupakan fitur tambahan (add-in) dalam aplikasi Microsoft Excel, sehingga lebih mudah digunakan dibanding aplikasi anyLogistix ${ }^{28,29}$. Sedangkan anyLogistix merupakan perangkat lunak yang digunakan untuk mendesain rantai pasok dan membuat simulasi sekaligus mengelola rantai pasok dalam satu aplikasi ${ }^{30}$. Tiga macam perangkat tersebut digunakan untuk melakukan simulasi Monte Carlo, dimana anyLogistix merupakan aplikasi paling unggul untuk digunakan industri karena memiliki fitur terlengkap. Ketiga aplikasi dapat digunakan dalam simulasi Monte Carlo ${ }^{31,32}$.

Salah satu contoh dari simulasi Monte Carlo pernah diterapkan dalam studi oleh Izadi dan Kimiagari tahun 2014 yang membahas tentang desain jaringan distribusi yang dipengaruhi oleh permintaan pelanggan yang bersifat tidak pasti pada suatu perusahaan farmasi di Iran $^{33}$. Selain itu, studi kasus yang dilakukan oleh Gunawan dan Simatupang juga menggunakan simulasi Monte Carlo untuk mencari skenario operasional rantai pasok terbaik bagi sebuah perusahaan farmasi di Indonesia untuk mencapai persentase pemenuhan pesanan 100\%. Studi tersebut dilakukan berdasarkan data operasional perusahaan seperti data permintaan dan penjualan produk milik perusahaan tersebut ${ }^{34}$.

Sebuah studi analisis simulasi rantai pasok akibat COVID-19 oleh Ivanov dengan perangkat lunak anyLogistix menunjukkan bahwa faktor utama penyebab dampak wabah COVID-19 terhadap performa rantai pasok industri adalah durasi penutupan fasilitas yang digunakan dalam rantai pasok serta tingkat persebaran kasus wabah COVID-19, dimana semakin lama waktu penutupan fasilitas distribusi COVID-19 maka semakin buruk performa operasional rantai pasok suatu perusahaan. Selain itu, semakin besar skala persebaran wabah COVID-19 di berbagai wilayah dunia menyebabkan penurunan daya operasional rantai pasok. Peristiwa ini dinamakan sebagai ripple effect yang dapat didefinisikan sebagai sebuah dampak yang ditimbulkan akibat gangguan rantai pasok yang menjalar ke berbagai titik pada jaringan rantai pasok. 
Upaya mitigasi yang dapat dilakukan untuk mengatasi ripple effect adalah dengan memiliki fasilitas distribusi cadangan seperti memiliki lebih dari satu sumber pasok atau multiple sourcing, serta memilih sumber pasok dengan lokasi berbeda untuk meminimalisasi risiko terganggunya rantai pasok ${ }^{35,36}$.

Langkah esensial lain yang dapat dilakukan oleh industri sebagai respons terhadap COVID-19 adalah melakukan manajemen informasi. Hal ini dapat dilakukan mulai dari melacak serta menggali informasi terbaru setiap saat terkait perkembangan situasi terkini serta melakukan komunikasi secara kontinu dengan pihak internal serta eksternal. Komunikasi terhadap pihak eksternal oleh industri farmasi juga hendaknya dilakukan secara proaktif dengan para pemasok di daerah terdampak khususnya terkait kontrak antara industri farmasi sebagai pembeli dan pihak pemasok. Selain melakukan kontak dengan pihak eksternal, industri farmasi juga sebaiknya melakukan komunikasi dalam lingkup internal.

Hal ini disebabkan karena situasi lapangan yang dinamis menuntut industri farmasi menentukan keputusan yang cepat dan efisien. Upaya yang dapat dilakukan oleh industri adalah dengan menggunakan konsep war room. Konsep war room adalah strategi dalam rantai pasok yang mengedepankan prinsip integrasi informasi, perencanaan sekaligus implementasinya pada satu platform secara simultan. Konsep war room merupakan strategi pertemuan dengan pihak-pihak tertentu untuk mengkaji eksekusi langkah bisnis yang dilakukan pada satu media. Kelebihan konsep war room adalah sifatnya yang dinamis, karena seluruh informasi dikumpulkan, diolah, dan ditindaklanjuti secara simultan oleh setiap personel kunci dari masing-masing departemen, seperti departemen Sales, Produksi, Supply Chain Planning, Pengadaan, dan Customer Service. Selain itu, seluruh pihak yang terlibat berada dalam satu platform, sehingga keputusan dapat dibuat dengan lebih cepat dan proses alur rantai pasok menjadi lebih efisien dan efektif ${ }^{37}$.

Industri farmasi sebagai badan yang bergerak di bidang bisnis tidak bisa terlepas dari faktor finansial sebagai pendukung kegiatan operasional. Aspek finansial merupakan salah satu aspek penggerak jalannya rantai pasok. Industri farmasi perlu memberi perhatian terhadap faktor finansial yang terpengaruh akibat pandemi ini. Data dari Bank Indonesia menunjukkan bahwa nilai tukar rupiah terhadap dolar Amerika Serikat menunjukkan tren pelemahan dari hari ke hari. Hal ini berdampak terhadap perusahaan-perusahaan yang mengandalkan impor untuk kegiatan operasionalnya seperti halnya industri farmasi di Indonesia.

Beberapa upaya bisa dilakukan oleh industri farmasi dalam segi finansial. Sebagai contoh, sejumlah perusahaan farmasi dalam negeri seperti Phapros dan Indofarma mulai menggenjot ekspor obat-obatan untuk meningkatkan pendapatan sebagai upaya mengatasi fluktuasi harga bahan baku obat akibat wabah virus corona ini ${ }^{38}$. Upaya tersebut dinamakan sebagai natural hedging, yaitu strategi manajemen keuangan menyeimbangkan pemasukan dan pengeluaran untuk mengurangi risiko finansial seperti nilai tukar mata uang ${ }^{39}$. 


\section{Kesimpulan}

Walaupun krisis perbekalan farmasi akibat COVID-19 kini belum terbilang signifikan, jika pandemi ini terus berlanjut maka stok dari perbekalan farmasi serta bahan baku farmasi berpotensi kian menipis yang dapat menyebabkan kelangkaan dalam skala yang lebih besar. Industri farmasi sebaiknya tetap melakukan pemantauan terhadap perkembangan situasi di lapangan dan meninjau rencana dan tindakan secara cermat terkait situasi yang dinamis setiap harinya.

\section{Daftar Pustaka}

1. Huang, C., Y. Wang, X. Li, L. Ren, J. Zhao, Y. Hu et al. Clinical features of patients infected with 2019 novel coronavirus in Wuhan, China. The Lancet. 2020;395(10223):497-506.

2. WHO. Coronavirus disease (COVID-19) outbreak situation. [diunduh 24 April 2020]. Tersedia dari: https://www.who.int/emergencies/diseases/novel-coronavirus-2019

3. BNPB. Dashboard Pemantauan Kasus COVID-19. [diunduh 24 April 2020]. Tersedia dari: https://bnpb-inacovid19.hub.arcgis.com

4. He, L. The coronavirus could cost China's economy $\$ 60$ billion this quarter. Beijing will have to act fast to avert a bigger hit. [diunduh 22 April 2020]. Tersedia dari: https://edition.cnn.com/2020/01/31/economy/china-economy-coronavirus/index.html

5. Langston, R. Capital Economics: Coronavirus to cost global economy over $\$ 280 \mathrm{bn}$. [diunduh $22 \quad$ April 2020]. $\quad$ Tersedia dari https://www.trustnet.com/news/7461746/capital-economics-coronavirus-to-costglobal-economy-over-\$280bn.

6. OECD. Coronavirus: The world economy at risk. [diunduh 22 April 2020]. Tersedia dari: https://www.oecd.org/berlin/publikationen//nterim-Economic-Assessment-2March-2020.pdf

7. Kozlenkova, I., G. T. M. Hult, D. J. Lund, J. A. Mena, and P. Kekec. The Role of Marketing Channels in Supply Chain Management. Journal of Retailing. 2015; 91(4): 586-609.

8. Kinra, A., D. Ivanov, A. Das, and A. Dolgui. Ripple effect quantification by supplier risk exposure assessment. International Journal of Production Research. 2019;1-20.

9. Ivanov, D., A. Dolgui, and B. Sokolov. Handbook of Riplle Effects in the Supply Chain. New York: Springer; 2019.

10. Schmitt, T. G., S. Kumar, K. E. Stecke, F. W. Glover, and M. A. Ehlen. Mitigating disruptions in a multi-echelon supply chain using adaptive ordering. Omega. 2017; 68: $185-98$. 
11. Ozili, P. K. and T. Arun. Spillover of COVID-19: impact on the Global Economy. SSRN Electronic Journal. 2020;1-20.

12. Rude, J.. Global Pharmaceutical Supply Chain at Risk from Coronavirus. [diunduh 19 Mei 2020]. Tersedia dari: https://blog.euromonitor.com/global-pharmaceuticalsupply-chain-at-risk-from-coronavirus/

13. Ramadhani, P. I. Bahan Baku Impor dari China, Industri Farmasi Kena Dampak Wabah Corona. [diunduh 19 Mei 2020]. Tersedia online di https://www.liputan6.com/bisnis/read/4199302/bahan-baku-impor-dari-china-industrifarmasi-kena-dampak-wabah-corona\#

14. Mukherji, B. Coronavirus: Indian firm brace for China supply shock as shutdown extends. [diunduh 19 Mei 2020]. Tersedia online di https://www.livemint.com/news/india/indian-firms-brace-for-china-supply-shock-asshutdown-extends-11581266850122.html

15. Sukmana, Y. Industri farmasi diminta cari alternatif bahan baku dari luar China. [diunduh 19 Mei 2020]. Tersedia online di https://money.kompas.com/read/2020/02/28/213100426/industri-farmasi-dimintacari-alternatif-bahan-baku-dari-luar-china

16. Ministry of Commerce \& Industry. 2020. Notification No. 50/ 2015-2020. [diunduh 20 April 2020]. Tersedia dari: https://dgft.gov.in/sites/default/files/Noti\%2050 0.pdf

17. Thomas, V. F. GP Farmasi Sebut Pasokan Bahan Baku Obat Masih Cukup Hingga April. [diunduh 20 April 2020]. Tersedia dari: https://tirto.id/gp-farmasi-sebutpasokan-bahan-baku-obat-masih-cukup-hingga-april-eEkX.

18. GlobalData. $95 \%$ of healthcare professionals concerned about coronavirus impact on their companies, says GlobalData. [diunduh 21 April 2020]. Tersedia dari: https://www.globaldata.com/95-of-healthcare-professionals-concerned-aboutcoronavirus-impact-on-their-companies-says-globaldatal

19. AstraZeneca. Our priorities responding to the COVID-19 outbreak. [diunduh 21 April 2020]. Tersedia dari: https://www.astrazeneca.com/media-centre/articles/2020/ourupdate-on-covid-19.html

20. Pfizer. How Pfizer is Respoding: Our Commitment to Support Continued Health and Safety. [diunduh 21 April 2020]. Tersedia dari: https://www.pfizer.com/health/coronavirus/how-pfizer-is-responding

21.GSK. GSK FAQs on COVID-19. [diunduh 21 April 2020]. Tersedia dari: https://www.gsk.com/en-gb/media/resource-centre/our-contribution-to-the-fightagainst-2019-ncov/gsk-faqs-on-covid-19/ 
22. Fiksel, J., M. Polyviou, K. L. Croxton, and T. J. Pettit. From risk to resilience: learning to deal with disruption. MIT Sloan Management Review. 2015;56(2):79-86.

23. Jüttner, U. and Maklan. S. Supply chain resilience in the global financial crisis: an empirical study. Supply Chain Management: An International Journal. 2011;16(4):246-59.

24. Reeves, M., N. Lang, and P. Carlsson-Szlezak. Lead Your Business Through the Coronavirus Crisis. [diunduh 21 April 2020]. Tersedia dari: https://hbr.org/2020/02/lead-your-business-through-the-coronavirus-crisis

25. Klibi, W. and A. Martel. Modeling approaches for the design of resilient supply networks under disruptions. Int. J. Production Economics. 2012;135:882-98.

26. Ivanov, D. Structural Dynamics and Resilience in Supply Chain Management. Cham: Springer International Publishing; 2018.

27. Hajian-Heidary, M. and A. Aghaie. Risk measurement in the global supply chain using monte-carlo simulation. JIEMS. 2012;2(2):1-12.

28.Palisade. @RISK. [diunduh 20 Mei 2020]. Tersedia dari: https://www.palisade.com/risk/default.asp

29. Oracle. Crystal Ball. [diunduh 20 Mei 2020]. Tersedia dari: https://www.oracle.com/technetwork/middleware/crystalball/overview/crystal-ball131398.pdf

30. The AnyLogic Company. Supply Chain Design \& Digital Twin Software Tool. [diunduh 20 Mei 2020]. Tersedia dari: https://www.anylogistix.com/what-is-alx/

31. Aldrighetti, R., I. Zennaro, S. Finco, and D. Battini. Healthcare Supply Chain Simulation with Disruption Consideration: A Case Study from Northern Italy. 2019; Global Journal of Flexible Systems Management. 2019;81-102.

32. Olson, D. and D. Wu. Risk management models for supply chain: a scenario analysis of outsourcing to China. Supply Chain Management: An International Journal. 2011;16(6):401-8.

33. Izadi, A. and A. M. Kimiagari. Distribution network design under demand uncertainity using genetic algorithm and Monte Carlo simulation approach: a case study in pharmaceutical industry. J Ind Eng Int. 2014;10(50):1-9.

34. Gunawan, I. L. dan T. Simatupang. Pharmaceutical product distribution with demand information sharing. IJISM. 2014;9(1):74-93.

35. Ivanov, D. Predicting the impacts of epidemic outbreaks on global supply chains: A simulation-based analysis on the coronavirus outbreak (COVID-19/SARS-CoV-2) case. Transportation Research Part E. 2020;136:101922. 
36. Dolgui, A., D. Ivanov, and B. Sokolov. Ripple effect in the supply chain: An analysis and recent literature. Int J Prod Res, Invited Special Issue 55 th Volume Anniversary of IJPR. 2018; 56(1-2):414-30.

37. Sapry, H. R. Md., A. R. Ahmad, M. Md. Zahid, and N. K. Soon. War Room Concept in the Context of Distribution Logistics. The Social Sciences. 2016;11(19):4609-12.

38. Rahayu, A.C. Sejumlah emiten BUMN farmasi lakukan natural hedging menghadapi pelemahan rupiah. [diunduh 6 April 2020]. Tersedia dari: https://industri.kontan.co.id/news/sejumlah-emiten-bumn-farmasi-lakukan-naturalhedging-menghalau-pelemahan-rupiah?page=all

39. Gong, S. and S. Cullinane. Finance and Risk Management for International Logistics and the Supply Chain. Amsterdam: Elsevier; 2018. 